\title{
Assessment of the influence of real-world radio station antennas
}

\author{
Paulo Henrique Sales Wanderley*, Marco Antônio Brasil Terada
}

\begin{abstract}
The boom in the use of cellular communications around the world lead to a significant increase in the number of radio base stations (herein referred to as "ERB") in populated areas. The main objective of this study is to show how the electromagnetic energy spreads out in the environment, and thus verify whether there is compliance with the current legislation in Brazil by analyzing the propagation characteristics through computer simulations. In order to quantify the electromagnetic propagation loss it is employed the model COST 231 by Ikegami-Walfisch (European..., 1996). It is also worthy mentioning that real measured data are employed to model the antennas in the ERBs. The influence of various system parameters are assessed and discussed in detail, such as the antenna side lobes, height of the tower in the ERB, antenna inclination angle and input power.
\end{abstract}

Keywords Applied electromagnetics, Antennas and propagation, Ikegami-Walfisch propagation model, Cellular communications, Brazilian legislation on radio frequency emissions, Computeraided design and simulations.

\section{Estudo da influência de antenas reais das estações rádio-base}

Resumo Com o aumento da utilização do sistema de telefonia celular, houve um crescimento notável no número de Estações Rádio-Base instaladas em localidades povoadas. Neste contexto, este trabalho pretende mostrar como as Estações Rádio-Base do sistema celular disseminam sua energia no ambiente que as circundam, e através da análise da propagação dessa energia, utilizando simulações computacionais, verificar se as emissões destes sistemas estão de acordo com a regulamentação vigente deste tipo de propagação. Para análise das perdas no caminho de propagação será utilizado o modelo de propagação de Ikegami-Walfisch. Neste trabalho se destaca também a utilização de modelos de antenas reais para realização destas simulações. Esta análise de perdas e a utilização de antenas reais aproximam as simulações da condição real do ambiente de propagação que será simulado. Nos casos em que as emissões destes sistemas não estejam em conformidade com a regulamentação vigente, este trabalho também analisa os fatores que geram estas inconformidades do ponto de vista dos parâmetros do sistema celular.

Palavras-chave Eletromagnetismo aplicado, Propagação eletromagnética e antenas, Modelo de propagação de Ikegami-Walfisch, Comunicações celulares, Legislação brasileira em emissões em radiofrequência, Simulações computacionais. 


\section{Introduction}

It is nowadays simply impossible to imagine our lives without wireless communications: cellular phones, wi-fi, Bluetooth, and WiMax networks are just a few examples of how deep the technology is inserted and molding our daily activities, constantly improving the way we relate to each other and providing invaluable means to access the tools and data we need for our personal and professional activities. Nowadays there are more than 6 billion cellular phones in operation, from wich about 242 million are in Brazil. Such numbers prove the strength of this technology and its importance in a wide range of fundamental services (International..., 2011).

A consistent technical knowledge of the possible biological effects of wireless communications is necessary, herein within the specific context of electromagnetic radiation, in order to clarify dubious and misleading information that sometimes impair the advance and development of new services, and even risk the use of the already implemented ones. The users have the right and need to be informed of coherent scientific results in order to use the wireless services with peace of mind. However, in recent past years an incomplete technical understanding leaded to the proliferation of local and county laws in Brazil, as well as consistent federal legislation (Agência..., 2002; 2004; Brazil, 2004; 2009; Palmas, 2008; São Paulo, 2004), in attempt to restrict the installation and use of radio base stations (herein referred to as ERBs) in populated areas, a few of which also causing justifiable concerns within the general population.

The Brazilian National Telecommunications Agency (ANATEL), as well as legislative authorities throughout the country, implemented laws and legislation to control the installation and usage of ERBs, in order to ensure the safety of the population exposed to the electric, magnetic and electromagnetic fields originated by radio frequency transmissions. This work investigates the sensitivity of the electromagnetic radiation due to various parameters, presenting and discussing the results within the context of the aforementioned legislation (Agência..., 2002; 2004; Brazil, 2004; 2009; Palmas, 2008; São Paulo, 2004).

\section{Methods}

According to article 19 of the annex to resolution $n^{\circ} 303 / 2002$ by ANATEL, measurements are only required to prove compliance when the theoretical results are equal or higher than $2 / 3$ (two thirds) of the estipulated limits for radiated emissions. Thus computer simulations are essential in the process of regulating the installation and operation of ERBs.
In several of the local and county laws, the distance between the base of the ERB and the populated areas is the main parameter to permit whether an ERB can be installed and operated. However the distance is not the only parameter that determines the intensity of the electromagnetic field radiated by an antenna. There are several other parameters that may alter significantly the electric field intensity radiated by an antenna, such as the installation height of the antenna, the height from the ground of observation point, the inclination angle, the effective radiated power of the system, and the radiation pattern of the antenna (considering both the main and side lobes). Figure 1 shows the geometrical parameters mentioned above.

The main challenge in designing and manufacturing an efficient antenna is to guarantee that most of the radiate power is radiated to the desired directions, or coverage, at the same time that interference to and from other systems is minimized (Saunders and Aragón-Zavala, 2007). Within this context we can visualize the antenna as one of the main elements in the development of any wireless communication system. In order to reach a sustainable operation, parameters such as the radiation pattern, directivity/ gain, cross polarization and bandwidth need to be considered in detail. The antenna herein employed is commercially available and used in many real wireless communication systems currently in operation.

\section{Antenna Andrew DB844G65ZAXY (Commscope Company, 2009)}

The horizontal and vertical diagrams of the antenna are shown in Figure 2 and Table 1 lists its electrical performance values and limits.

Another factor that influences the way how intensity of electromagnetic field is distributed in space is the propagation loss. The correct evaluation of losses during propagation is essential for the determination of the electric field intensity that reaches the population.

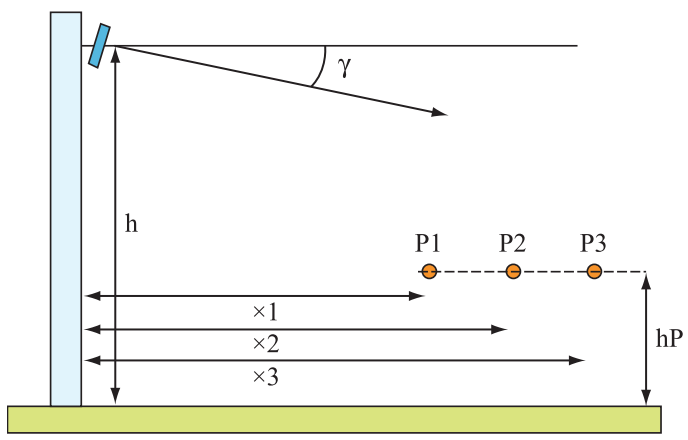

Figure 1. Geometrical parameters for calculating the electric field intensity emitted by the antenna. 
Among the various existing models to estimate these losses, there is the COST 231 Ikegami-Walfisch model (European..., 1996) which was chosen in this study (Instituto..., 2005). This model was developed to calculate the loss in the path of propagation in urban environments for systems with operation frequency between $800 \mathrm{MHz}$ and $2 \mathrm{GHz}$, and it was based on the models of Ikegami (Terada et al., 2005) and Walfisch-Bertoni (Godara, 2001).
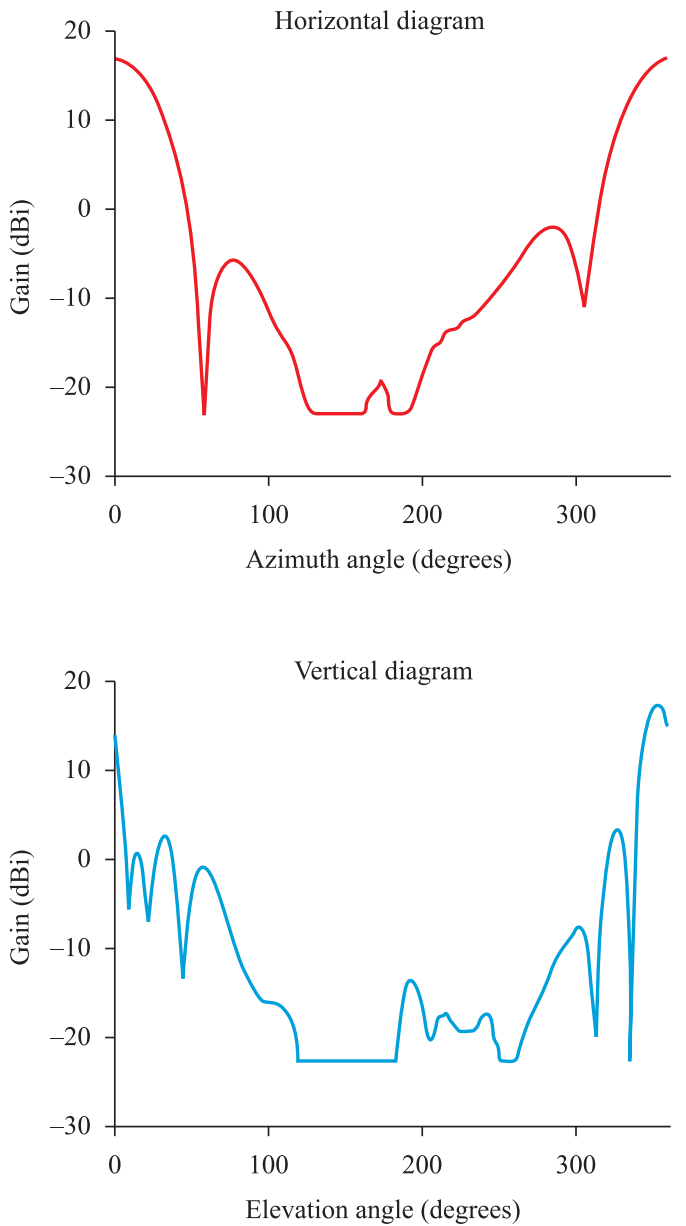

Figure 2. Measured antenna patterns of the antenna Andrew DB844G65ZAXY.

Table 1. Performance parameters for the antenna DB844G65ZAXY.

\begin{tabular}{lc}
\hline \multicolumn{1}{c}{ Parameters } & Values \\
\hline Bandwidth & $806-896 \mathrm{MHz}$ \\
Gain & $16.85 \mathrm{dBi}$ \\
Height & $1.22 \mathrm{~m}$ \\
Minimum distance of far-field & $8.89 \mathrm{~m}$ \\
Maximum EIRP* & $64 \mathrm{dBm}$ \\
Maximum allowed input power & $51.88 \mathrm{~W}$ \\
\hline
\end{tabular}

*Effective Isotropic Radiated Power.
Basically, the model considers the propagation loss evaluated by the free-space model. When there is no line of sight between the antenna and the point of observation, the model also considers the losses by multiple diffractions occurred in buildings that surround the transmission and the diffraction losses on top of obstacles, as well as losses caused by scattering in the streets and roads.

The parameters that the model considers for evaluation of losses are (distances in meters):

- $d$, distance between the transmitter and the receiver antenna;

- $h_{\text {base }}, h_{\text {mobile }}$ and $h_{\text {roof }}$ that are ERB height, receiver antenna height and average building height, respectively;

- $b$, average distance between the constructions;

- $w$, average width of streets surrounding ERB;

- $\varphi$, angle between street orientation and incident wave, in degrees.

For situations where there is no line of sight (NLOS), the equations for loss evaluation defined for the Ikegami-Walfisch model are:

$$
L_{N L O S}=L_{F}+L_{m s d}+L_{s d}
$$

where $L_{F}$ are the losses for Free Space propagation, $L_{m s d}$ evaluates the multiple diffraction losses and $L_{s d}$ evaluates the losses on buildings rooftop diffractions. For the term $L_{s d}$ the equations are given bellow:

$L_{s d}=-16.9+10 \cdot \log f_{c}+10 \cdot \log \frac{\left(h_{\text {roof }}-h_{\text {mobile }}\right)^{2}}{w}+L_{\varphi}$

were

$L_{\varphi}=\left\{\begin{array}{lr}-10+0.354 \cdot \varphi & \text { for } 0^{\circ}<\varphi<35^{\circ} \\ 2.5+0.075\left(\varphi-35^{\circ}\right) & \text { for } 35^{\circ} \leq \varphi<55^{\circ} \\ 4.0+0.114\left(\varphi-55^{\circ}\right) & \text { for } 55^{\circ} \leq \varphi \leq 90^{\circ}\end{array}\right.$

And for the term $L_{m s d}$, the equation is:

$L_{m s d}=L_{b s h}+k_{a}+k_{d} \cdot \log d+k_{f} \cdot \log f_{c}-9 \cdot \log b$

where the constants $k_{a}, k_{d}$ and $k_{f}$ are given by:

$k_{a}= \begin{cases}54 & \text { for }\left(h_{\text {base }}>h_{\text {roof }}\right) \\ 54-0.8\left(h_{\text {base }}-h_{\text {roof }}\right) & \text { for }\left(h_{\text {base }} \leq h_{\text {roof }}\right) \text { and }(d \geq 0.5 \mathrm{~km}) \\ 54-0.8 \cdot \frac{\left(h_{\text {base }}-h_{\text {roof }}\right) \cdot d}{0.5} & \text { for }\left(h_{\text {base }} \leq h_{\text {roof }}\right) \text { and }(d<0.5 \mathrm{~km})\end{cases}$

$k_{d}= \begin{cases}18 & \text { for }\left(h_{\text {base }}>h_{\text {roof }}\right) \\ 18-15 \frac{\left(h_{\text {base }}-h_{\text {roof }}\right)}{h_{\text {roof }}} & \text { for }\left(h_{\text {base }} \leq h_{\text {roof }}\right)\end{cases}$

$k_{f}=-4+0.7\left(\frac{f_{c}}{925}-1\right)$ or $k_{f}=-4+1.5\left(\frac{f_{c}}{925}-1\right)$ 
The first equation of $k_{f}$ is used for medium cities and second is used for metropolitan centers.

The choice of this model to evaluate the losses in the propagation path was based on three parameters: precision, computational cost and easiness of adaptation to local conditions. The model showed good accuracy compared to models such as Free-Space and EarthFlat on general environments with obstacles in the propagation path. It is a model with relatively simple computational implementation. It is based on simple concepts and is easy to use. In order to fit the model to a specific environment it is simply necessary to adjust a few parameters.

The following values were chosen for the computer simulation herein presented, and are standard averages employed for most locations (Saunders and AragónZavala, 2007) but also compare well to real case scenarios in Brazilian cities, as well as necessary to investigate limiting cases that lead to overall conclusions.

$h_{\text {base }}$ equal to $10,20,30,40$ and 50 meters, $h_{\text {mobile }}=1.69 \mathrm{~m}$, which is the average height of an adult in Brazil (Instituto..., 2005); $w=30 \mathrm{~m}$, $b=15 \mathrm{~m}, h_{\text {roof }}=12 \mathrm{~m}$ and $\varphi=90^{\circ}$ (Saunders and Aragón-Zavala, 2007).

\section{Results}

\section{Behavior of the electric field intensity considering the losses evaluated with free-space and Ikegami-Walfisch models}

The height of the ERB tower was fixed at 30 meters, given that this is a common value encountered in many real situations (Terada et al., 2005). Figure 3 and Table 2 show the results for the computed values of the electric field intensity.

\section{Behavior of the electric field intensity considering changing the installation height of the antenna}

In this case three simulations were performed accordingly to the following antenna heights: 10, 20 and 30 meters. Again the Ikegami-Walfisch model was employed, and the value for the effective isotropic radiated power EIRP was set to the limit estipulated for the considered bandwidth in the Resolution no 376/2004 (Agência..., 2004). The inclination angle of the antenna is 8 degrees (Terada et al., 2005). Figure 4 and Table 3 show the results for the computed values of the electric field intensity.

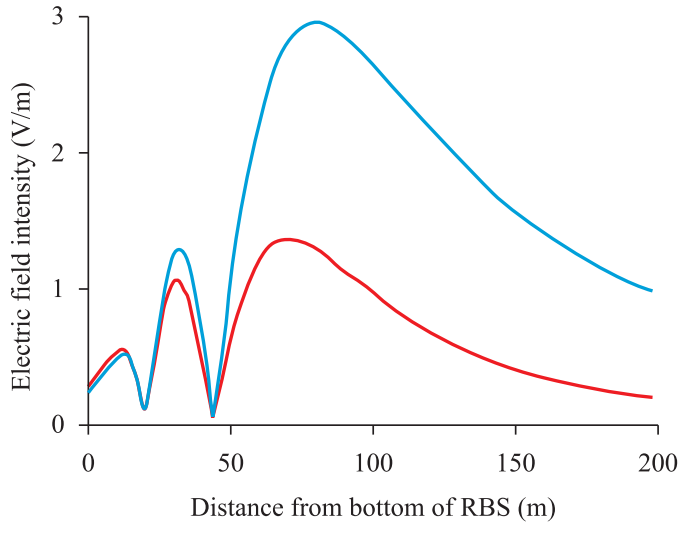

— loss evaluated for Ikegami-Walfisch model
_ loss evaluated for free-space model

Figure 3. Intensity of electric field depending on the distance $x$ from the base of the ERB tower, as computed with the free-space and Ikegami-Walfisch models.

Table 2. Values for the intensity of electric field depending on the distance $x$ from the base of the ERB tower, as computed with the free-space and Ikegami-Walfisch models.

\begin{tabular}{cccc}
\hline & & \multicolumn{2}{c}{ Model } \\
\cline { 3 - 4 } & & free-space & $\begin{array}{r}\text { Ikegami- } \\
\text { Walfisch }\end{array}$ \\
\cline { 2 - 4 } & $\begin{array}{r}\text { Distance } \boldsymbol{x} \\
\text { from ERB }\end{array}$ & $\begin{array}{c}\text { Intensity of electric field } \\
\text { (V/m) }\end{array}$ \\
\hline $\mathrm{A}$ & $20 \mathrm{~m}$ & 0.202 & 0.196 \\
$\mathrm{~B}$ & $50 \mathrm{~m}$ & 0.862 & 0.543 \\
$\mathrm{C}$ & $100 \mathrm{~m}$ & 2.673 & 0.984 \\
Maximum & variable & 2.956 & 1.368 \\
& & at $x=78 \mathrm{~m}$ & at $x=70 \mathrm{~m}$ \\
\hline
\end{tabular}

\section{Behavior of the electric field intensity considering changing the effective radiated power of the system}

In this section the results of three simulations are presented in Figure 5 and Table 4 as a function of the variation of the input power. In order to assess the worst-case scenario, the reference value for the EIRP is the maximum allowed accordingly to the current federal legislation (Agência..., 2004). The inclination angle of the antenna is 8 degrees (Terada et al., 2005) and the tower height is 30 meters (Agência..., 2004). The values of input power used in the simulations are as follows:

- Maximum allowed as the reference value;

- Half of the reference value;

- One third of the reference value. 


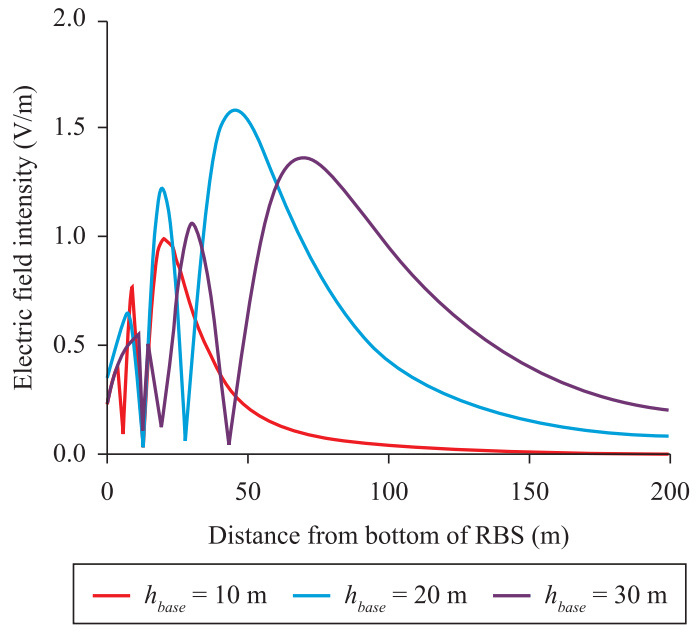

Figure 4. Intensity of electric field depending on the distance $x$ from the base of the ERB considering three tower heights for the antenna Andrew DB844G65ZAXY.

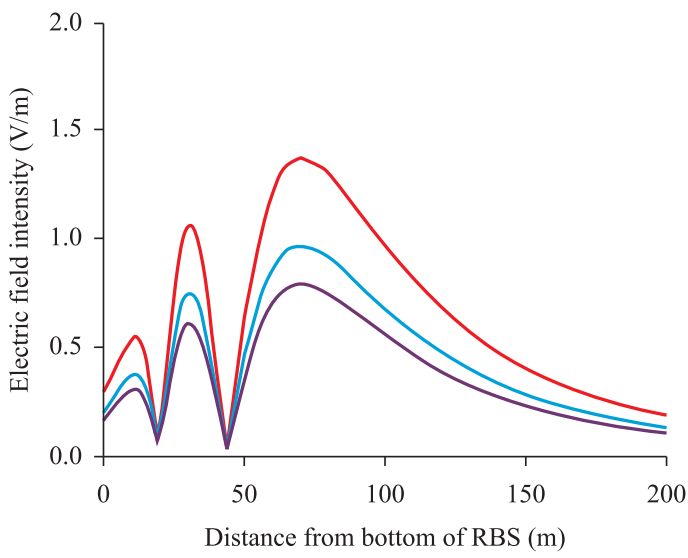

$-\mathrm{P}=51.88 \mathrm{~W}-\mathrm{P}=25.94 \mathrm{~W}-\mathrm{P}=17.29 \mathrm{~W}$

Figure 5. Variation of the electric field intensity as a function of the input power for the antenna Andrew DB844G65ZAXY.

Table 3. Values for the intensity of electric field considering three tower heights for the antenna Andrew DB844G65ZAXY.

\begin{tabular}{ccccc}
\hline & & \multicolumn{3}{c}{ Height of the ERB tower } \\
\cline { 2 - 5 } & & $\boldsymbol{h}_{\text {base }}=\mathbf{1 0} \mathbf{~ m}$ & $\boldsymbol{h}_{\text {base }}=\mathbf{2 0} \mathbf{~ m}$ & $\boldsymbol{h}_{\text {base }}=\mathbf{3 0} \mathbf{~ m}$ \\
\cline { 2 - 4 } & Distance $\boldsymbol{x}$ from ERB & \multicolumn{2}{c}{ Intensity of electric field (V/m) } \\
\hline A & $20 \mathrm{~m}$ & 0.981 & 1.237 & 0.122 \\
$\mathrm{~B}$ & $50 \mathrm{~m}$ & 0.187 & 1.544 & 0.543 \\
$\mathrm{C}$ & $100 \mathrm{~m}$ & 0.037 & 0.393 & 0.984 \\
Maximum & variable & 0.993 & 1.599 & 1.368 \\
& & at $x=21 \mathrm{~m}$ & at $x=45 \mathrm{~m}$ & at $x=70 \mathrm{~m}$ \\
\hline
\end{tabular}

Table 4. Computed values of the electric Field intensity as a function of the input power for the antenna Andrew DB844G65ZAXY.

\begin{tabular}{ccccc}
\hline & & \multicolumn{3}{c}{ Input power values } \\
\cline { 2 - 4 } & & $\mathbf{P}=\mathbf{5 1 . 8 8} \mathbf{~ W}$ & $\mathbf{P}=\mathbf{2 5 . 9 4} \mathbf{~ W}$ & $\mathbf{P}=\mathbf{1 7 . 2 9} \mathbf{~ W}$ \\
\cline { 2 - 4 } & Distance $\boldsymbol{x}$ from ERB & & Intensity of electric field (V/m) \\
\hline $\mathrm{A}$ & $20 \mathrm{~m}$ & 0.122 & 0.086 & 0.071 \\
$\mathrm{~B}$ & $50 \mathrm{~m}$ & 0.543 & 0.384 & 0.313 \\
$\mathrm{C}$ & $100 \mathrm{~m}$ & 0.984 & 0.696 & 0.568 \\
Maximum & $70 \mathrm{~m}$ & 1.348 & 0.968 & 0.790 \\
\hline
\end{tabular}

\section{Discussion}

In each of the computer simulations presented in the previous section there are specific conclusions that are worthy to look in detail before presenting the overall conclusions of the work.

Variation of the electric field with the employed propagation models

The following conclusions can be listed based on the results presented in Figure 3 and Table 2:

- Lower values for the electric field intensity are found when the propagation losses are computed with the Ikegami-Walfisch model, when compared with the free-space model;
- The maximum intensity of the electric field occurs at a point situated further than 50 meters from the ERB, a limit estipulated in a few local and county laws (Brasil, 2004; Palmas, 2008);

- The side lobes of the real antenna have a significant impact on the outcome of the results, changing the overall electrical behavior of the radio frequency emissions as a function of spatial locations.

\section{Variation of the electric field with the tower height}

In general, the electric field decreases as the tower height increases, as the observation point becomes 
further away (exceptions are discussed below). It is worth mentioning that the curves computed with the Ikegami-Walfisch approach the ones with the free-space loss as the tower height is increased (for example, 50 meters). The following specific conclusions can be listed based on the results presented in Figure 4 and Table 3:

- The lowest intensities of electric field were computed for a height of 10 meters due to the fact that the surrounding buildings have a stronger influence in attenuating the radiation. For higher heights, the overall conclusion previously mentioned applies, which is that the electric field decreases as the tower height increases;

- The maximum electric field intensity again occurs at distances close or further than 50 meters in several of the presented scenarios;

- As before, the side lobes of the real antenna alter the profile of how the intensity of the radiation reaches the population.

\section{Variation of the electric field with the input power}

The EIRP is obtained from the product of the input power by the antenna gain (linear quantities) (Godara, 2001; Stutzman and Thiele, 1997). The following conclusions are listed:

- The electric field intensity is directly proportional to the square root of the input power;

- The maximum electric field intensity again occurs at distances close or further than 50 meters in several of the presented scenarios;

- As before, the side lobes of the real antenna alter the profile of how the intensity of the radiation reaches the population.

\section{Other aspects}

It can also be observed at the computational simulations that the curves computed with the Ikegami-Walfisch approach the ones with the free-space loss as the tower height is increased, as shown by Figure 6 . The simulation was performed for an antenna height of 50 meters, an inclination angle of 8 degrees and the maximum allowed input power. Although in general a height of 50 meters does not correspond to real world situations (unless the tower is installed on the roof of a building). This height was chosen to investigate limiting scenarios.

It can be observed in Figure 6 the proximity of the curves for distances up to 80 meters. It can also be noted that for distances below 30 meters the computed results from the Ikegami-Walfisch model are higher than the ones with the free-space model. This can be explained by the fact that the Ikegami-
Walfisch model also considers the diffraction on the top of surrounding buildings, which depending on the phase of the signal increase the electric field.

Another additional conclusion is that the inclination angle has a siginificant impact on how the energy spreads out in the environment. An inclination close to zero degrees, resulting in the antenna parallel to the ground, results in emissions beyond the desired coverage. On the other hand, antennas pointing to the ground increase immensely the intensity of the electric field nearby the ERB (Terada, 2008). As a matter of fact, this in general happens for inclinations above 45 degrees. Therefore it is necessary to select an inclination such as the emission is not concentrated on the base of the ERB but also covers the desired area efficiently. Figure 7 shows the behavior of the electric field as a function of the antenna inclination angle. The values for the inclination employed in the simulations are based on real-world case examples (Terada et al., 2005).

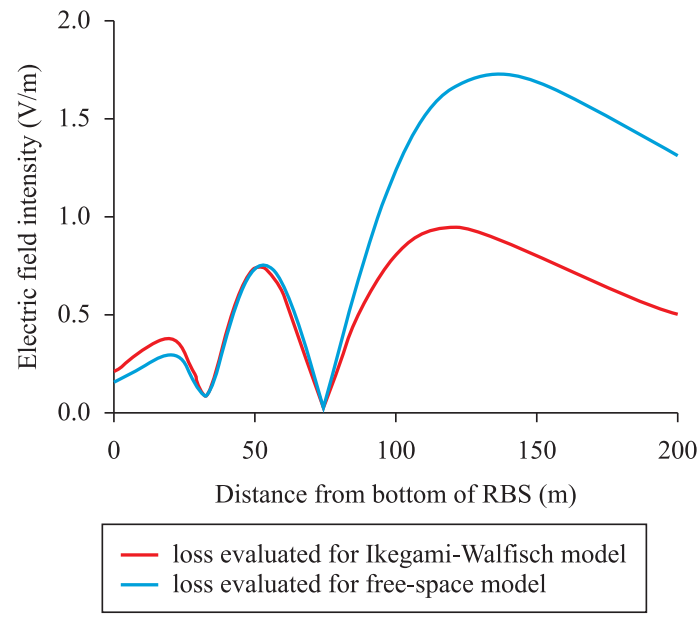

Figure 6. Comparison between the propagation models for a height of 50 meters.

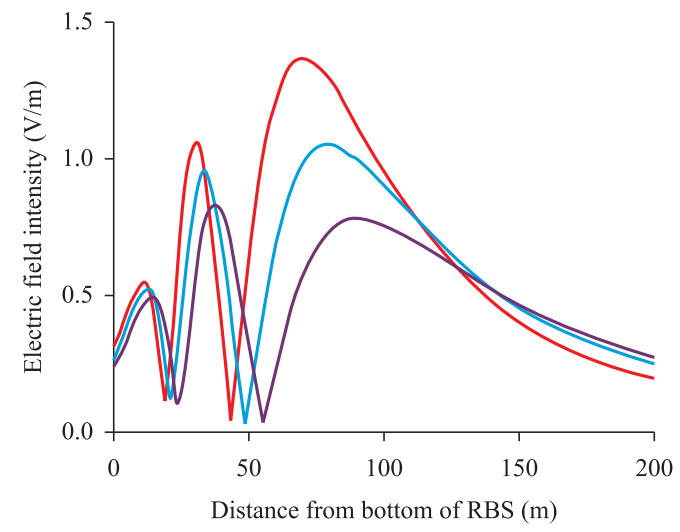

- tilt $=2$ degrees - tilt $=4$ degrees - tilt $=8$ degrees

Figure 7. Behavior of the electric field intensity as a function of the antenna inclination angle for the model Andrew DB844G65ZAXY. 


\section{Conclusions}

A sensitivity analysis of the electric field behavior as a function of the influence of various system parameters were conducted and discussed in detail, such as the antenna side lobes, height of the tower in the ERB (radio base station), antenna inclination angle and input power. Many of the aforementioned parameters are normally not considered, and most of the county laws issued through Brazil were based solely in the distance between the base of the ERB tower and the observation point (Terada, 2008). This is a technical incomplete assumption and may lead to an increase of the electric field intensity in the regions that the laws are trying to protect people.

The overall conclusion is that the only technically correct and safe scientific criteria to control the radiated emissions over the general population is to limit the value of the intensity of the electric field. This criteria is employed in (Agência..., 2002; São Paulo, 2004; Brazil, 2009). The resolution (Agência..., 2002) and laws (Brazil, 2009; São Paulo, 2004) establish that the spatial and temporal averages of the maximum electric field intensities is $41.1 \mathrm{~V} / \mathrm{m}$ for the general population in the bandwidth between 869 and $894 \mathrm{MHz}$ ("A" band of the mobile communications services in Brazil), and that the aforementioned intensity value should be the result of all wireless systems in operation. It is worthy mentioning that (Brazil, 2009) is a federal law that has been recently approved in Brazil.

Finally, a contribution of this work that is not normally accounted in other investigations is that not only the main lobe of the antenna should be considered, but the emissions from the side lobes can even be higher than the ones from the main lobe, varying with the antenna type and inclination, as well as the height of the ERB tower.

\section{References}

Agência Nacional de Telecomunicações - ANATEL. Resolução $n^{\circ} 303$, de 02 de julho de 2002. Aprova regulamento sobre limitação da exposição a campos elétricos, magnéticos e eletromagnéticos na faixa de radiofreqüências entre $9 \mathrm{kHz}$ e 300 GHz. Diário Oficial da República Federativa do Brasil, Brasília, DF, 10 jun. 2002.

Agência Nacional de Telecomunicações - ANATEL. Resolução ${ }^{\circ} 376$, de 2 de setembro de 2004. Aprova a alteração do regulamento sobre condições de uso de radiofreqüências nas faixas de $800 \mathrm{MHz}, 900 \mathrm{MHz}$ e $1.800 \mathrm{MHz}$ para prestação do serviço móvel pessoal. Diário Oficial da República Federativa do Brasil, Brasília, DF, 6 set. 2004.

Brasil. Câmara dos Deputados. Lei no 3446,23 de setembro de 2004. Estabelece normas para a instalação de torres destinadas a antenas de transmissão. Diário Oficial da República Federativa do Brasil, Brasília, DF, set. 2004.

Brasil. Congresso Nacional. Legislação Informatizada Lei $n^{\circ} 11.934$, de 5 de maio de 2009. Dispõe sobre limites à exposição humana a campos elétricos, magnéticos e eletromagnéticos; altera a Lei $\mathrm{n}^{\circ} 4.771$, de 15 de setembro de 1965; e dá outras providências. Diário Oficial da República Federativa do Brasil, Brasília, DF, 6 maio 2009.

Commscope Company. [cited 2009 Dec.]. Available from: http://awapps.commscope.com/catalog/andrew/product_ details.aspx?id=15523

European Cooperation in Scientific and Technical Research COST. Digital mobile radio : COST 231 view on the evolution towards 3rd generation systems. Bruxelas: COST; 1996.

Godara LC. Handbook of antennas in wireless communications. CRC Press; 2001.

Instituto Brasileiro de Geografia e Estatística - IBGE. Inquérito às despesas, 2002-2003, Microdados. IBGE; 2005.

International Telecommunication Union - ITU. World Telecommunication / ICT Indicators Database 2011. 15th ed. Geneva: ITU; 2011.

Palmas. Câmara Municipal. Lei Complementar no 164, 17 junho de 2008. Dispõe sobre o processo de licenciamento para a instalação e funcionamento dos sistemas de transmissores de radiação eletromagnética não ionizante, Estações Rádio-Base - ERB, de telefonia celular no município de Palmas e dá outras providências. Boletim Oficial Tribunal de Contas do Estado do Tocatins, Palmas, TO, jun. 2008.

São Paulo. Câmara Municipal. Lei Municipal no 13756, 16 de janeiro de 2004. Dispõe sobre a instalação de Estação Rádio-Base - ERB, no Município de São Paulo, e dá outras providências. Diário Oficial do Estado de São Paulo, São Paulo, SP, jan. 2004.

Saunders SR, Aragón-Zavala A. Antennas and propagation for wireless communication systems. 2th ed. John Wiley \& Sons; 2007.

Stutzman WL, Thiele GA. Antenna theory and design. 2th ed. John Wiley \& Sons; 1997.

Terada MAB. Análise da intensidade de campo elétrico de estações rádio-base. Telecomunicações. 2008; 11:54-59.

Terada MAB, Menezes LR, Carvalho PHP. Sistemas de telefonia celular: Respondendo ao chamado da razão. Brasília: Universidade de Brasília - UnB; Associação Nacional das Operadoras Celulares - ACEL; 2005. v. 1, 40 p.

\section{Authors}

Paulo Henrique Sales Wanderley, Marco Antônio Brasil Terada

Departamento de Engenharia Elétrica, Faculdade de Tecnologia - FT, Universidade de Brasília - UnB, CP 04591, CEP 70910-900, Brasília, DF, Brasil 